has shown that it is a form of the attached species, while Dr. J. D. Robertson's work on the chemistry of the body fluids in octopus and squids has shown that the 'kidney' of these animals may have an important role in maintaining the relative levels of different metals in their bodies.

In geography and geology the researches were mainly geological but covered a very wide range. Particular reference is made to surveys of the geology of the Elburz Mountains, north-east of Teheran, by Sir Edward Bailey, and of the geology of Ubekandt Island in West Greenland, by Dr. H. I. Drever. Work on the spores of recent and fossil microspores in archegoniate plants has been continued by Mrs. E. A. Knox, and special mention is made of excava tions carried out at Kafizin, Cyprus, by Mr. T. B. Mitford, leading to the collection for the Cyprus Museum of some five hundred inscribed sherds.

The report of the superintendent of the laboratory of the Royal College of Physicians, also appended, refers to the death of Dr. R. C. Low, who had been curator and superintendent since January 1 , 1945, as well as to the loss of Dr. W. O. Kermack, head of the Biochemical Department, on taking up his appointment as professor of biological chemistry in the University of Aberdeen (see Nature, 162, 604; 1948). Drs. J. C. Lees and W. W. Park have published the report of a study of the histological appearances of cancer at different ages and are preparing a review of the pathology of the cancer of the thyroid, while Drs. T. W. Lees and J. C. Lees have submitted for publication a report of a comparison between the lethal doses and the tumour-inhibiting doses in mice of several drugs. Dr. E. K. Dawson continued her histological investigations and completed a third study of sarcoidosis. Workers in the Chemistry Department of the College were occupied chiefly in completing the synthesis of compounds of possible chemotherapeutic activity, with special reference to malaria, filariasis and amœbiasis. 4-Diethylpropylamino-p-phenanthroline has now shown considerable activity in tests on chicks infected with $P$. gallinaceum, but some benzthiazole derivatives proved inactive against filarial infections of cotton-rats. Mrs. Storey and Miss Cairns completed their researches on benzcarbolines and quinoquinolines, and on azanthracenes and linear benzacridines, respectively, and Dr. Miller his study of the chloride content and electrical conductivity of human milk.

\section{JOHN HANSON: A MAKER OF MICROSCOPE SLIDES}

$\mathrm{T}$ HE history of the development of science in Great Britain abounds with the names of many whose training did not embrace all that is usually considered necessary for the professional scholar. Some had a sound early education, some were entirely self-taught. Some, such as Landen, remained 'amateurs' throughout their lives, while others, such as Thomas Simson, achieved professional status by their sole efforts.

From scientific correspondences to be found in such periodicals as the Gentleman's Magazine and the Lady's Magazine and from the minutes of oldfounded local societies, one can conclude that there were many others who by example and interest and by occasional positive contributions have helped in the development. There are also men who have been similarly active but who, through the circumstances of their positions, have not been fortunate enough to have had any record made, published or unpublished, of their interests. The gradual tabulation of the men of both these classes and of their interests would be a valuable adjunct to the lists of the work and achievements of the 'known' students of science. It could well be done by the individual inquiries of the trained men and women spread over the country in the teaching profession.

John Hanson, of the West Riding of Yorkshire, is one who falls into the latter group, and, although his death is as recent as 1890 , his singular self-taught ability in the manufacture of slides for the microscope is already forgotten. His early days were spent working on a farm at Crossland Moor, near Huddersfield, where an interest in matters theological is perpetuated by hi ; endorsement "John Hanson's, Crossland Moor, 1853" in "An Exposition to the Creed" by John Pearson, D.D. The volume bears a large number of marginal notes in a shorthand of his own devising. A kick on the chest by a horse, which affected his breathing throughout the rest of his life, forced him to a less strenuous occupation, and he moved to the Leeds area. On July 3, 1853, and on April 9, 1854, he preached three sermons at the Muff Field Chapel, Bradford, of the Wesleyan Reform Movement, and became full minister of this Chapel and of the Park Lane Chapel of the same town, in 1860, resigning in 1866. It is from the recollections of a former member of this Chapel, now elderly, who was in contact with John Hanson for the last twenty years of his life, and from the scanty records of the Chapel, that the information in this article has in the main been drawn. $\mathrm{He}$ is remembered as a big powerful man with a clear speech, though somewhat laboured from his injury, and with a strongly revivalistic style. His biological and botanical studies were already prominent, and, on his leaving, members of his pastorate, subscribing twenty guineas, presented him with a Beck microssope. This microscope with its equipment and some of his own slides was until recently in good condition; it met with misadventure while on loan to one worse placed than Hanson himself. He later held a pastorate at Grantham, returning to Leeds, his wife's home town, in about 1870.

Throughout his life, John Hanson was in poor financial circumstances, and his last years, between his wife's death and his own in 1890, were spent with his sisters-in-law in Leeds, where he had a single room which he used both as a bedroom and as a work-room. A regular purchase of Nature was his only indulgence. With home-made apparatus he eked out a scanty living by the manufacture of microscope slides, in which art he obtained such fame that he was called on to supply a laboratory in Downing College, Cambridge, with slides to such a number that a printed list was required. He also acted as an agent for the supply of small scientific instruments ( $\mathrm{I}$ have in my possession a small telescope which originally was from this source), and occasionally gave scientific lectures. He was a prolific writer of tracts on religious matters; but these could have been of little financial profit to himself (and were certainly not to his printers), but one of them is of special interest as it also advertises a list of his popular scientific lectures-the microscope, the telescope, life upon earth, Darwinism, insects, animal physiology, vegetable physiology, astronomy and geology. H. GWYNEDD GREEN 